\title{
Cyanobacteria microflora in a limestone spring (Troniny spring, Central Poland)
}

\author{
Paulina Bronisława Nowicka-Krawczyk*, Joanna Żelazna-Wieczorek \\ Department of Algology and Mycology, University of Łódź, Banacha 12/16, 90-237 Łódź, Poland
}

\begin{abstract}
The paper reports a study of cyanobacterial diversity in a cold-water limestone limnocrene in Central Poland. Samples were collected from 1998 to 2000 and in June 2012. The morphology, population characteristics and species composition of the cyanobacteria assemblages were investigated, and the frequency of taxa was recorded. The large number of taxa identified (30) reflects the microhabitat heterogeneity of this spring. Some species considered epiphytes grew on limestone rocks. The occurrence of the majority of the most frequent taxa was related to the physicochemical characteristics of the spring, but none of them can be considered obligatory crenobionts characteristic of limestone springs. The studied spring is a unique ecosystem with an interesting cyanobacteria microflora whose occurrence is attributable to the spring's water chemistry, low temperature and variety of microhabitats.
\end{abstract}

Keywords: cyanobacteria, calciphilic species, crenobionts, limestone spring, morphology

\section{Introduction}

Spring niches are unique habitats. They differ from other surface waters in the physical and chemical stability of their water parameters [1]. The low temperature and specific chemistry of spring waters makes them an interesting habitat for studying biocenoses. Springs are also very sensitive to human impacts. Increasing urbanization and changes in agricultural practices lead to eutrophication and may lower the water table enough to halt discharge of groundwater to the land surface.

Most springs in Central Poland can be considered oligotrophic habitats, in which various forms of nitrogen and phosphorus ions occur at low concentrations [2]. Stable thermic and hydrochemical conditions and low trophic state distinguish these springs from other types of surface water ecosystem in Poland.

The algal microflora of springs in Central Poland has been examined before. Rakowska [3] conducted long-term research on diatoms of a karstic limnocrene in the vicinity of Łódź, and Żelazna-Wieczorek [4] analyzed the stability of diatom assemblages in springs from Quaternary formations. Neither one reported the presence of cyanobacteria in the springs.

\footnotetext{
*Corresponding author. Email: paulina_nowicka84@interia.pl Handling Editor: Andrzej Bodył

This is an Open Access digital version of the article distributed under the terms of the Creative Commons Attribution 3.0 License (creativecommons.org/licenses/by/3.0/), which permits redistribution, commercial and non-commercial, provided that the article is properly cited.
}

Cyanobacteria occur worldwide in a wide variety of habitats. They are one of the main primary producers of organic compounds, and under extreme conditions they often are the only autotrophic organisms in a biocenosis $[5,6]$. The oligo- and stenothermic conditions of spring waters in Central Poland make spring fens an attractive habitat for cyanobacteria. Some of the springs occur on limestone substrate, and in such habitats cyanobacteria occur at much higher frequency [7]. Many of the calciphilic cyanobacterial species have the ability to precipitate calcium carbonate and thereby play a key role in creating travertine formations $[1,8,9]$.

This study of a limestone spring in Central Poland was intended to document the species richness of cyanobacteria inhabiting a calcareous, oligo- and stenothermic environment, to determine whether the most frequent species are associated with the calcareous substrate, and to track any temporal changes in their species composition in the spring, which is characterized by stable environmental conditions.

\section{Material and methods}

Troniny spring $\left(51^{\circ} 5^{\prime} 54.98^{\prime \prime} \mathrm{N} ; 18^{\circ} 43^{\prime} 30.44^{\prime \prime} \mathrm{E}\right)$ is located in Załęczański Landscape Park on the old bed of the Warta River between Troniny and Stara Wieś villages (Fig. 1). The spring is a karstic limnocrene and the water alimenting the spring flows through Tertiary sedimentary rock and then discharges at the bottom of a basin-like depression, forming a water reservoir roughly $8 \mathrm{~m}$ wide and $25 \mathrm{~m}$ long. The bottom is covered by mud-sand and calcareous stones with macrophytes (Elodea canadensis Michx.) and macroalgae (Vaucheria sp.) growing locally on the bottom. The banks of the reservoir are covered with trees (mainly Betula alba L., Alnus glutinosa Gaertn. and 


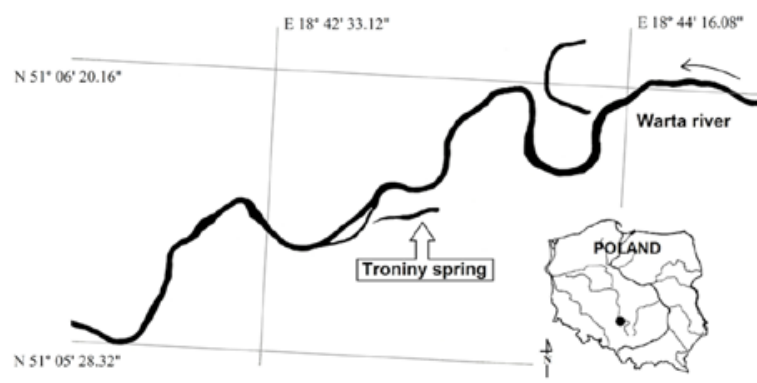

Fig. 1 Location of Troniny spring.

Pinus silvestris L.) which contribute much wood, leaves and other material to the spring.

For the observations we used archive samples of cyanobacteria collected between 1998 and 2000 (deposited in the Department of Algology and Mycology, University of Łódź) and samples collected 12-14 years later in June 2012 from different microhabitats of the spring. For the purpose of this analysis all archive samples were regarded as representing one sampling period. Six archive samples and eight samples from 2012 were analyzed. Most were epilithic cyanobacteria, and some were benthic (from mud-sand substrate), epixylic (on submerged wood) and epiphytic (on algae and macrophytes). All the samples were preserved in $4 \%$ formaldehyde. They were observed with a Nikon YS 100 light microscope at $400 \times$ and $1000 \times$. Color slides were taken with a Nikon Coolpix E5400 and used to prepare drawings. For identification, morphological and population diagnostic characters were compared with the most important characters given in the literature for each cyanobacterial group [10-13], based on the classification of Komárek \& Anagnostidis [14-18]. Following Cantonati et al. [19], species frequency is given on a 4-point scale (modified, with 0 for taxa not observed): 1 - single or few specimens; 2 - infrequent, 3 - frequent, 4 - very frequent.

The water chemistry of the spring was analyzed in the Laboratory of the Environmental Protection Inspectorate in Łódź.

\section{Results and observations}

The groundwater chemistry reflects the lithology of the aquifer. There were no substantial differences in water chemistry between the two sampling periods. The tested water was cold $\left(8.3-9.3^{\circ} \mathrm{C}\right.$ ), and slightly alkaline (avg. $\mathrm{pH} 7.5$ ). Due to the limestone substrate, the spring water had high total carbonate hardness (avg. $\left.170 \mathrm{mval} / \mathrm{dm}^{3}\right)$, magnesium $\left(2.4 \mathrm{mg} / \mathrm{dm}^{3}\right)$, and calcium $\left(60.3 \mathrm{mg} / \mathrm{dm}^{3}\right)$. The water also had low nitrates (avg. $\left.4.7 \mathrm{mg} / \mathrm{dm}^{3}\right)$ and total phosphorus $\left(0.1 \mathrm{mg} / \mathrm{dm}^{3}\right)$. Its high conductivity (avg. $318 \mu \mathrm{S}$ ) was related more to the aquifer's lithology than to anthropogenic loads of biogens. The water's low nitrates and phosphorus and the absence of direct sources of pollution allow this habitat to be classified as oligotrophic.

In the 14 samples we identified 30 cyanobacterial taxa belonging to 22 genera (Tab. 1). The most frequent species among the cyanobacteria assemblages from the archive samples were Tapinothrix varians (Geitler) Bohunická et Johansen, macroscopically visible on rocks as dark spots, and Phormidium favosum Gomont ex Gomont, forming steel-blue/green cyanobacteria mats attached to stones. Aphanocapsa rivularis (Carmichael) Rabenhorst and Pleurocapsa minor Hansgirg also occurred frequently on calcareous rocks. The identified taxa were species preferring limestone substrate and/or cold unpolluted waters $[11,12]$. No clear dominance of taxa was observed in the samples collected in 2012. Only five taxa were considered infrequent, and the others were represented by only a few specimens. The lower species frequency in 2012 was accompanied by slightly higher species richness (16 in 1998-2000, 20 in 2012).

A variety of substrates were available for colonization (stones, macroalgae, macrophytes) in the spring niche. Epilithic and epiphytic cyanobacteria species were recorded. Typical epilithic species such as Aphanocapsa rivularis (Carmichael) Rabenhorst and Tapinothrix varians (Geitler) Bohunická et Johansen were noted, along with Chamaesiphon confervicolous A. Braun in Rabenhorst, Ch. starmachii Kann, Heteroleiblenia kuetzingii (Schmidle) Compčre and Xenotholos kernerii (Hansgirg) GoldMorgan et al. growing on stones. Only two cyanobacteria species occurred exclusively as epiphytes: Chamaesiphon amethystinus (Rostafinski) Lemmermann and Ch. incrustans Grunow in Rabenhorst. The first was found on Vaucheria sp. filaments, and the second on Elodea canadensis stalks.

Only six taxa occurred in both sets of samples (Fig. 2): Aphanocapsa rivularis (Carmichael) Rabenhorst, Geitlerinema splendidum (Greville ex Gomont) Anagnostidis, Gloeocapsopsis sp., Merismopedia glauca (Ehrenberg) Kützing, Pseudanabaena frigida (Fritsch) Anagnostidis and Tapinothrix varians (Geitler) Bohunická et Johansen.

Among the archive samples we observed an interesting stigonematalean [18] cyanobacteria thallus (Fig. 3a-c) attached to stony substrate together with other periphytic algae. It consisted of a basal layer of cells with a nematoparenchymatous arrangement of radially oriented filaments. Trichomes were pseudodichotomously divaricated with true V-type branching. The cells were irregular, with homogenous content, forming trichomes surrounded by sheaths. Heterocytes were present but were solitary and intercalary, and no akinetes were observed.

\section{Discussion}

Though cyanobacteria apparently are common in cold-water springs, studies of this group of organisms in that habitat are rare. The studies that have been done, dealing with springs located in different regions and varying in character, do not support the idea that there are spring-specific species or that particular species are associated exclusively with crenon hydrobiology $[19,20]$. In Poland there have been no longitudinal studies focused only on cyanobacteria and conducted regularly at different types of springs.

In terms of the hydrobiology of spring types, cyanobacteria occur most commonly in rheocrenes and limnocrenes; in helocrenes they show low diversity and are replaced by green algae $[19,21]$. This probably is due to the difference in the ability of cyanobacteria and green algae to use carbon dioxide at high and low $\mathrm{pH}$ [22].

The number of cyanobacteria taxa in Troniny spring (30) seems fairly high. Forty taxa were reported from 19 springs in northern Italy [19], and 51 from 32 springs in the Western Carpathians [23]; both of those studies were of mountain springs, mainly rheocrenes. Due to its size and available substrates, Troniny spring can be considered a heterogeneous mosaic of aquatic and semi-aquatic microhabitats. Higher habitat complexity means more microhabitats of different types and higher biodiversity [24], reflected here in higher cyanobacterial 


\begin{tabular}{|c|c|c|c|c|}
\hline & \multicolumn{2}{|c|}{ Abundance } & \multicolumn{2}{|c|}{ Occurrence } \\
\hline & 1998-2000 & 2012 & 1998-2000 & 2012 \\
\hline Aphanocapsa muscicola (Meneghini) Wille & 2 & 0 & epilithic & n.o. \\
\hline Aphanocapsa rivularis (Carmichael) Rabenhorst & 3 & 1 & epilithic & epilithic \\
\hline Aphanothece cf. caldariorum Richter & 0 & 2 & n.o. & epilithic \\
\hline Aphanothece microscopica Nägeli & 0 & 1 & n.o. & metaphytic ${ }^{3}$ \\
\hline Chamaesiphon amethystinus (Rostafinski) Lemmermann & 0 & 1 & n.o. & epiphytic ${ }^{3}$ \\
\hline Chamaesiphon confervicolus A. Braun in Rabenhorst & 2 & 0 & epilithic & n.o. \\
\hline Chamaesiphon incrustans Grunow in Rabenhorst & 0 & 1 & n.o. & epiphytic ${ }^{4}$ \\
\hline Chamaesiphon starmachii Kann & 0 & 1 & n.o. & epilithic \\
\hline Chlorogloea sp. & 0 & 2 & n.o. & epilithic \\
\hline Geitlerinema amphibium (Agardh ex Gomont) Anagnostidis & 0 & 1 & n.o. & epixylic \\
\hline Geitlerinema splendidum (Greville ex Gomont) Anagnostidis & 3 & 1 & epilithic & benthic \\
\hline Gloeocapsopsis sp. & 1 & 1 & epilithic & epilithic \\
\hline Heteroleblenia kuetzingii (Schmidle) Compère & 0 & 2 & n.o. & epilithic \\
\hline Jaaginema pseudogeminatum (Schmid) Anagnostidis et Komárek & 2 & 0 & epilithic & n.o. \\
\hline Leptolyngbya sp. & 0 & 1 & n.o. & epilithic \\
\hline Lyngbya cf. martensiana Meneghini ex Gomont & 0 & 1 & n.o. & benthic \\
\hline Merismopedia glauca (Ehrenberg) Kützing & 1 & 1 & metaphytic ${ }^{2}$ & metaphytic ${ }^{4}$ \\
\hline Oscillatoria limosa Agardh ex Gomont & 0 & 1 & n.o. & benthic \\
\hline Phormidiochaete crustacea (Borzì ex Bornet et Flahault) Bohunická et Johansen & 0 & 2 & n.o. & epilithic \\
\hline Phormidium favosum Gomont ex Gomont & 4 & 0 & epilithic & n.o. \\
\hline Phormidium setchellianum Gomont & 0 & 1 & n.o. & epilithic \\
\hline Phormidium umbilicatum (Nägeli) Gomont & 1 & 0 & epilithic & n.o. \\
\hline Pleurocapsa minor Hansgirg & 3 & 0 & epi-/endolithic & n.o. \\
\hline Pseudanabaena frigida (Fritsch) Anagnostidis & 2 & 2 & epilithic & epilithic \\
\hline Pulvinularia sp. & 1 & 0 & epilithic $^{1}$ & n.o. \\
\hline Rhabdoderma sp. & 1 & 0 & epilithic ${ }^{1}$ & n.o. \\
\hline Synechocystis sp. & 0 & 1 & n.o. & epilithic \\
\hline Tapinothrix varians (Geitler) Bohunická et Johansen & 4 & 1 & epilithic & epilithic \\
\hline Woronichinia cf. tenera (Skuja) Komárek et Hindák & 1 & 0 & epilithic ${ }^{1}$ & n.o. \\
\hline Xenotholos kerneri (Hansgirg) Gold-Morgan et al. & 1 & 0 & epilithic & n.o. \\
\hline
\end{tabular}

${ }^{1}$ on stones covered by periphyton; ${ }^{2}$ among Phormidium sp. filaments; ${ }^{3}$ among and on Vaucheria sp.; ${ }^{4}$ among and on Elodea canadensis. n.o. - not observed.

diversity. This case challenges the assumption that helocrenes generally are most heterogeneous in terms of microhabitat and that limnocrenes are least heterogeneous [25]. Habitat heterogeneity depends on the particular spring: size of the spring niche, the distribution of substrates favoring colonization, and other conditions like flow velocity [26].

The macroalgae and macrophytes in the spring niche create a suitable microhabitat for epiphytic cyanobacteria. Epiphytism is determined by the presence or absence of the host and by the succession of epiphytes during the season [27]. Certain cyanobacteria species usually considered epiphytes, such as Chamaesiphon confervicolus A. Braun in Rabenhorst, Ch. starmachii Kann and Xenotholos kernerii (Hansgirg) Gold-Morgan et al., rarely show the ability to colonize rocky substrate $[11,21]$ and thus do not bind obligatorily with their host.

A feature of springs is environmental stability, so seasonal dynamics usually are not expected in spring ecosystems. Seasonal changes in light intensity, moisture and water discharge may be an important variable for the dynamics of cyanobacteria assemblages. Those factors are more decisive in rheocrenes $[1,26]$. Since Troniny spring is a relatively large and persistent limnocrene with little variability of flow, seasonal dynamics were not observed. Changes in species richness and frequency over the study period may therefore be related to changes in land use around the spring. Formerly the banks of the old bed of the Warta River were a summer recreation area, with many summerhouses and a swimming pool for holidaymakers. The absence of sewers and sewage treatment in the area may also have affected the spring ecosystem in those days. In the early 20th century the area ceased to be a resort and the surroundings of the spring reverted to a more natural state.

Some of the taxa occurred at higher frequency in both periods of the study. Species such as Aphanocapsa rivularis (Carmichael) Rabenhorst, Tapinothrix varians (Geitler) Bohunická et Johansen, Phormidiochaete crustacea (Borzě ex Bornet et Flahault) Bohunická et Johansen, Phormidium favosum Gomont ex Gomont and Pleurocapsa minor Hansgirg prefer calcareous environments, occurring in limestone areas $[11,12,28]$. These species can be regarded as calcitolerant and calciphilic. Some species considered characteristic of eutrophic and polluted waters were also noted in the springs. Among them, Oscillatoria limosa Agardh ex Gomont and Geitlerinema splendidum (Greville ex Gomont) Anagnostidis were known previously from oligothermic semi-mineral springs $[29,30]$. 
a
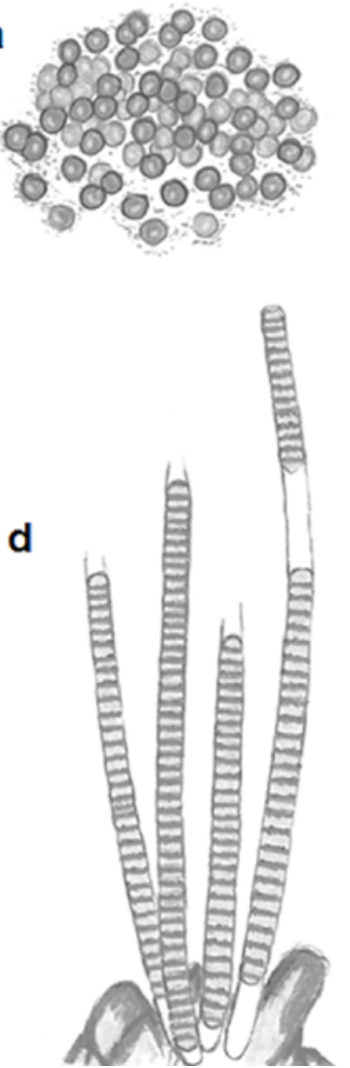

b

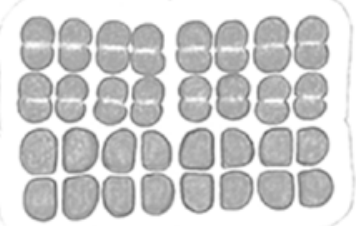

C

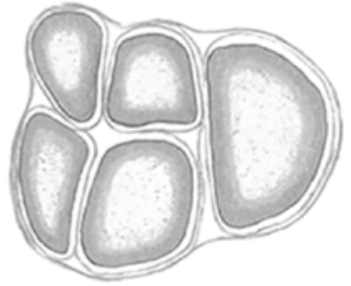

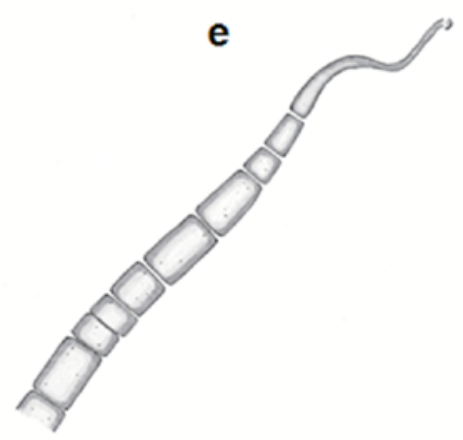

f

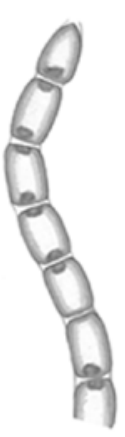

Fig. 2 The six cyanobacteria species noted in both sets of samples (1998-2000 and 2012). a Aphanocapsa rivularis. b Merismopedia glauca. c Gloeocapsopsis sp. d Tapinothrix varians. e Geitlerinema splendidum. f Pseudanabaena frigida. Scale bars: $10 \mu \mathrm{m}$ for a-e; $5 \mu \mathrm{m}$ for f.
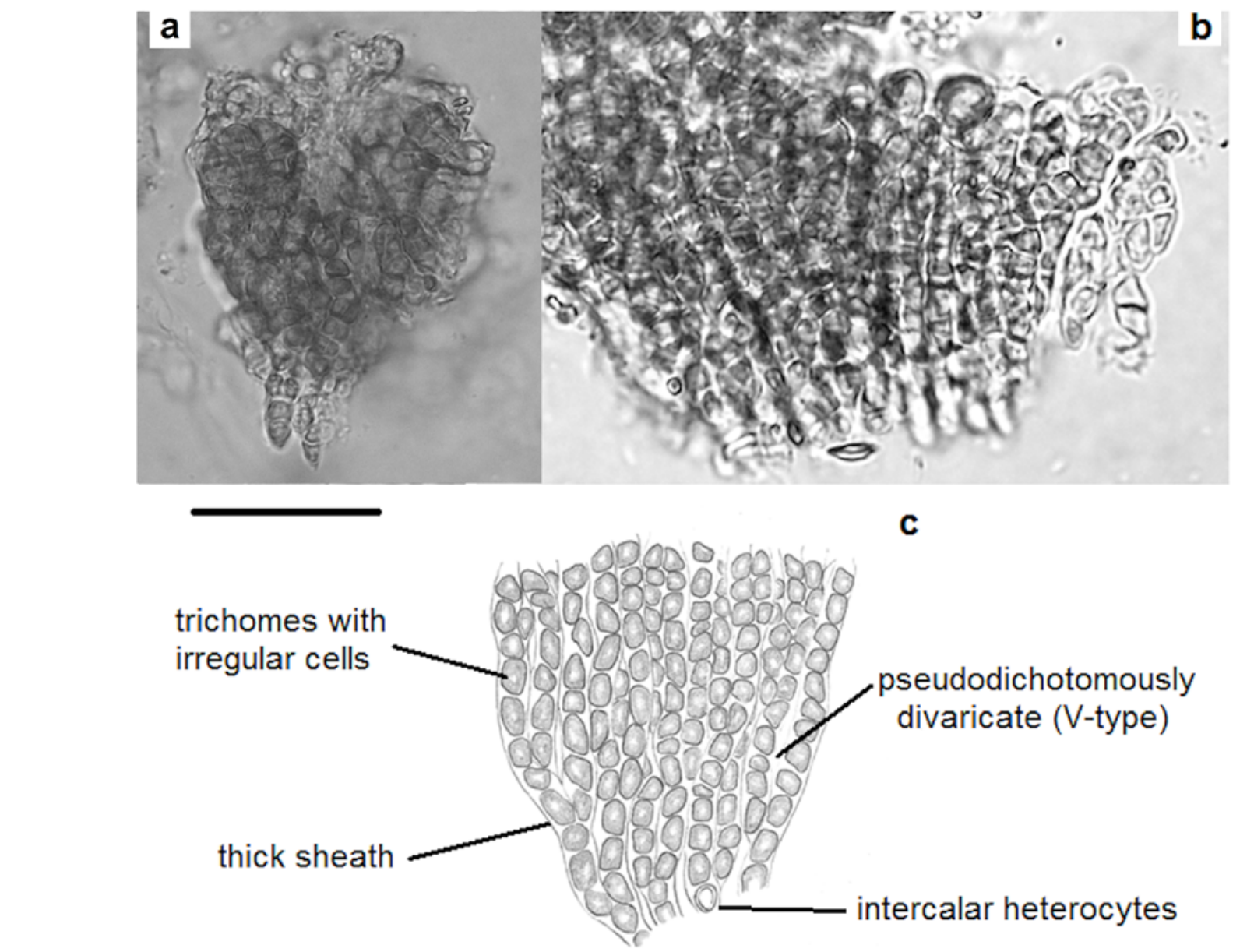

b

Fig. 3 a-c Stigonematalean thallus from Troniny spring. Scale bar: $25 \mu \mathrm{m}$. 
Their occurrence in a limestone spring confirms their wider range of habitat.

The studied limnocrene is a unique aquatic ecosystem in which its specific chemistry, low temperature and diversity of microhabitats support an interesting cyanobacteria microflora. None of the identified cyanobacteria taxa are associated exclusively with limnocrenes, nor are they characteristic of them. Species such as Merismopedia glauca (Ehrenberg) Kützing, Xenotholos kernerii (Hansgirg) Gold-Morgan et al., Pleurocapsa minor Hansgirg, Jaaginema pseudogeminatum (Schmid) Anagnostidis et Komárek and Phormidium setchellianum Gomont have been noted in coldwater springs [12,19,23,29] but cannot be considered obligatory crenobionts because springs are not the sole type of ecosystem in which they occur.

The interesting stigonematalean cyanobacteria thallus we found resembled the monospecific genus Pulvinularia in most features [31,32], although with some differences from the type species Pulvinularia suecica [32,33]. The differences relate to the distribution of cells in trichomes and the shape of the sheath. The cells were tightly arranged in filaments, with no septal areas visible between neighboring cells. The sheaths were thin, homogenous and colorless, closely attached to the trichomes. In the apical part of the filament the sheath became indistinct. The radially orientated filaments were also very tightly arranged. Morphologically this thallus was very similar to one found in Borzago spring in Adamello-Brenta National Park, Italy, and identified as Pulvinularia sp. [18,19,21], so we use the temporary name Pulvinularia sp. in Tab. 1. The ecology of specimens from Troniny spring varies from the type species of the genus Pulvinularia, P. suecica Borzi, so far the only known species of this genus, first described in epiphytic material from lakes in Sweden [31]. Much later it was rediscovered growing epilithically in another Swedish lake [32]. From the data in those reports, $P$. suecica might be considered a species with lentic ecosystem preferences, but some populations within the metric and morphological limits of $P$. suecica were discovered as epilithic in tropical lotic ecosystems in Brazil [33]. Pulvinularia sp. sensu Cantonati [19] was also found as epilithic at high elevation in a lotic ecosystem, a rheocrene. In all cases cited it was noted in oligotrophic ecosystems not under anthropopression. The possible presence of Pulvinularia sp. specimens in Troniny spring is not surprising in view of the ecological conditions of the other ecosystems mentioned for it, but the taxonomy of this stigonematalean thallus needs to be confirmed.

\section{Acknowledgments}

We are indebted to anonymous reviewers for their comments and valuable suggestions for previous version of manuscript. We are also indebted to Michael Jacobs for correction of our English. This research was supported by the University of Łódź task grant for a young researcher No. B1311000000100.02.

\section{Authors' contributions}

The following declarations about authors' contributions to the research have been made: field research, laboratory work, determination, photographs and drawings, writing the manuscript, bibliography studies: PNK; field research, writing the manuscript, bibliography studies: JZW.

\section{References}

1. Poulícková A, Hašler P, Kitner M. Cyanobacteria and algae. In: Poulícková A, Hájek M, Rybnícek K, editors. Ecology and palaeoecology of spring fens of the West Carpathians. Olomouc: Palacký University Press; 2005. p. $105-130$.

2. Kociolek PJ, Stoermer EF. Oligotrophy: the forgotten end of an ecological spectrum. Acta Bot Croat. 2009;68(2):465-472.

3. Rakowska B. Diatom communities occurring in Niebieskie Źródła near Tomaszów Mazowiecki, central Poland (1963-1990). Fragm Flor Geobot. 1996;41(2):639-655.

4. Żelazna-Wieczorek J. Diatom flora in springs of Łódź Hills (Central Poland). Biodiversity, taxonomy, and temporal changes of episammic diatom assemblages in springs affected by human impact. In: Witkowski A, editor. Diatom Monographs. Ruggell: A.R.G. Ganter Verlag K.G; 2011. p. 1-419. (vol 13).

5. Kremer B. Mat-forming coccoid cyanobacteria from early Silurian marine deposits of Sudetes, Poland. Acta Palaeontol Pol. 2006;51(1):143-154.

6. Golubić S. Encounters with greater bacteria. Period Biol. 2010;112(3):227-238.

7. Czerwik-Marcinkowska J, Uher B. Cyanophytes on limestone rocks in the Szopczański Gorge (Pieniny Mountains) - their ecomorphology and ultrastructure. Acta Soc Bot Pol. 2011;80(3):205-209. http://dx.doi. org/10.5586/asbp.2011.013

8. Davis RA, Reas C, Robbins LL. Calcite mud in a Holocene back-barrier lagoon; Lake Reeve, Victoria, Australia. J Sediment Res. 1995;65(1a):178-184. http://dx.doi.org/10.1306/D4268063-2B26-11D7-8648000102C1865D

9. Kaźmierczak J, Coleman ML, Gruszczyński M, Kempe S. Cyanobacterial key to the genesis of micritic and peloidal limestones in ancient seas. Acta Palaeontol Pol. 1996;41(4):319-338.

10. Starmach K. Cyanophyta - sinice, Glaucophyta - glaukofity. In: Starmach K, editor. Flora słodkowodna Polski. Warsaw: Polish Scientific Publishers PWN; 1966. p. 1-753.

11. Komárek J, Anagnostidis K. Cyanoprokaryota I. In: Ettl H, Gärtner G, Heynig H, Mollenhauer D, editors. Süßwasserflora von Mitteleuropa 19/1. Stuttgart: G. Fischer; 1999. p. 1-548.

12. Komárek J, Anagnostidis K. Cyanoprokaryota II. In: Büdel B, Gärtner G, Krienitz L, Schagerl M, editors. Süßwasserflora von Mitteleuropa 19/2. Munich: Elsevier GmbH; 2005. p. 1-757.

13. Bohunická M, Johansen JR, Fučiková K. Tapinothrix clintonii sp. nov. (Pseudoanabaenaceae, Cyanobacteria), a new species at the nexus of five genera. Fottea. 2011;11(1):127-140.

14. Anagnostidis K, Komárek J. Modern approach to the classification system of cyanophytes. 1 - Introduction. Arch Hydrobiol Suppl Algol Stud. 1985;38-39:291-302.

15. Komárek J, Anagnostidis K. Modern approach to the classification system of cyanophytes. 2 - Chroococcales. Arch Hydrobiol Suppl Algol Stud. 1986;43(2):157-226.

16. Anagnostidis K, Komárek J. Modern approach to the classification system of cyanophytes. 3 - Oscillatoriales. Arch Hydrobiol Suppl Algol Stud. 1988;50-53:327-472.

17. Komárek J, Anagnostidis K. Modern approach to the classification system of Cyanophytes 4 - Nostocales. Arch Hydrobiol Suppl Algol Stud. 1989;56:247-345.

18. Anagnostidis K, Komárek J. Modern approach to the classification system of Cyanophytes. 5 - Stigonematales. Arch Hydrobiol Suppl Algol Stud. 1990;59:1-73.

19. Cantonati M, Rott E, Pipp E. Ecology of cyanophytes in mountain springs of the River Sarca catchment (Adamello-Brenta Regional Park, Trentino, Northern Italy). Arch Hydrobiol Suppl Algol Stud. 1996;83:145-162.

20. Whitford LA, Schumacher GJ. Communities of algae in North Carolina streams and their seasonal relations. Hydrobiologia. 1963;22(1-2):133-196. http://dx.doi.org/10.1007/BF00039686 
21. Cantonati M. La microflora. In: Cantonati M, editor. Le sorgenti del Parco Adamello-Brenta. Strembo: Parco Adamello-Brenta; 1998. p. 55-101. (Parco Documenti; vol 11).

22. Glime JM, Vitt DH. A comparison of bryophyte species diversity and niche structure of montane streams and stream banks. Can J Bot. 1987;65(9):1824-1837. http://dx.doi.org/10.1139/b87-252

23. Hašler P, Poulícková A. Cyanobacteria of the West Carpathian Mts spring fens: single samplings. Czech Phycol. 2005;5:43-55.

24. Scarsbrook MR, Barquín J, Gray DP. New Zealand coldwater springs and their biodiversity. Wellington: Science \& Technical Publishing; 2007.

25. Bhat SU, Pandid AK. Ecological study of benthic communities in three limnocrene freshwater springs of Kashmir Himalaya. J Nat Sci Math. 2010;3(2):89-96.

26. Cantonati M, Gerecke R, Bertuzzi E. Springs of the Alps - sensitive ecosystems to environmental change: from biodiversity assessments to long-term studies. Hydrobiologia. 2006;562(1):59-96. http://dx.doi. org/10.1007/s10750-005-1806-9

27. Kučera P, Uher B, Komárek O. Epiphytic cyanophytes Xenococcus kerneri and Chamaesiphon minutus on the freshwater red alga Paralemanea catenata (Rhodophyta). Biologia (Bratisl.). 2006;61(1):11-13. http://dx.doi. org/10.2478/s11756-006-0002-3

28. Starmach K. Homoeothrix crustacea Woronichin and accompanying algae in the upper course of the river Raba. Acta Hydrobiol. 1966;8(3-4):309-320.

29. Marinović ŽR. Algen in den Quellen des Flusses Gradac. Bot Serb. 1955;1(1):9-22.

30. Ligowski R. Glony rzeki Bobrówki. Zesz Nauk Uniw Ł Nauk Mat-Przyr. 1974;2(54):135-162.

31. Borzi A. Studi suelle Mixoficee. II. Stigonemataceae. Nuovo Gior Bot Ital. 1916;23:559-588.

32. Rott E, Hernández-Mariné M. Pulvinularia suecica, a rare stigonematalean cyanophyte. Arch Hydrobiol Suppl Algol Stud. 1994;75:313-322.

33. Branco LHZ, Hoffmann L, Necchi O, Taboga SR, Moura ENM. Branch formation in Pulvinularia suecica; (Nostocales, Cyanoprokaryota) and considerations on the classification of dichotomously and pseudodichotomously branched genera. Nova Hedwig. 2010;90(1):95-104. http://dx.doi. org/10.1127/0029-5035/2010/0090-0095 